\title{
Nursing Care in Healthcare-Associated Infections: A Scoping Review
}

\author{
Cuidado de enfermagem nas Infecções Relacionadas à Assistência à Saúde: Scoping review \\ Cuidado de enfermería en las Infecciones Relacionadas con la Asistencia Sanitaria: Scoping review
}

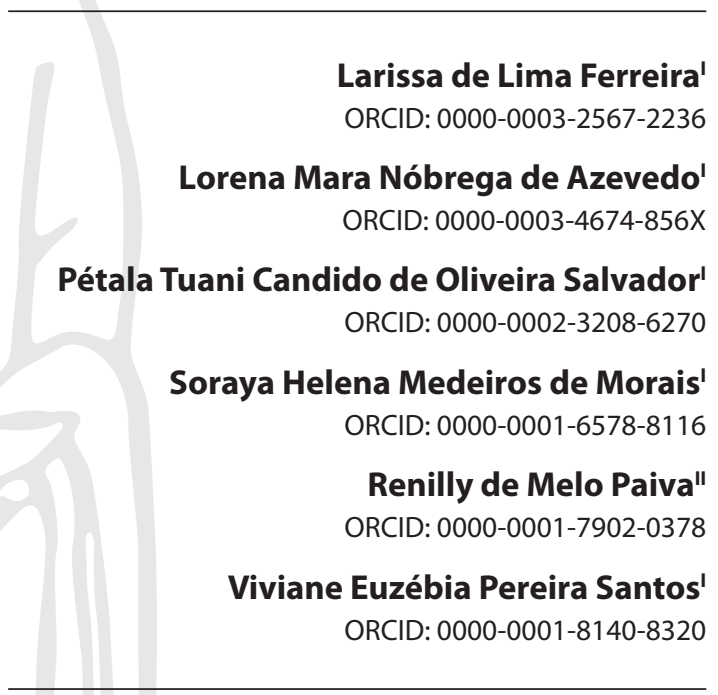

' Universidade Federal do Rio Grande do Norte. Natal-RN, Brasil. "Universidade Potiguar. Natal-RN, Brasil.

How to cite this article: Ferreira LL, Azevedo LMN, Salvador PTCO, Morais SHM, Paiva RM, Santos VEP. Nursing care in Healthcare-Associated Infections: a Scoping Review. Rev Bras Enferm. 2019;72(2):476-83. doi: http://dx.doi.org/10.1590/0034-7167-2018-0418

\begin{abstract}
Corresponding Author:
Larissa de Lima Ferreira

E-mail: lariiilf@gmail.com
\end{abstract}

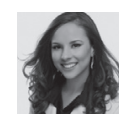

Submission: 06-14-2018

Approval: 08-08-2018

\section{ABSTRACT}

Objective: To identify and map nursing care to the adult patient with HealthcareAssociated Infections admitted to the Intensive Care Unit. Method: Scoping Review, conducted in January 2018, through the search of studies in national and international databases, journals, catalogs of theses and dissertations, and websites of Brazilian health institutions. We included full surveys published in the Portuguese, Spanish or English language; which had as object of study the researched subject, besides manuals and protocols. We analyzed the type of material, year, country, population, method, Level of Evidence, and nursing care. The final sample consisted of 33 publications. Results: Among the nursing care to the patient, hand hygiene was identified, general care in nursing procedures, use of protocols, effective communication and periodic training. Conclusion: Identifying patient care with infection was important in order to list methods and reorient nursing activities.

Descriptors: Intensive Care Units; Nursing; Healthcare-Associated Infections; Nursing Care; Patients.

\section{RESUMO}

Objetivo: Identificar e mapear os cuidados de enfermagem ao paciente adulto com Infecções Relacionadas à Assistência à Saúde internado em Unidade de Terapia Intensiva. Método: Scoping Review, realizado em janeiro de 2018, mediante busca de estudos em bases de dados, revistas, catálogos de teses e dissertações nacionais e internacionais, além de sites de instituições brasileiras de saúde. Incluem-se pesquisas publicadas na íntegra na língua portuguesa, espanhola ou inglesa; que tinham como objeto de estudo a temática investigada, além de manuais e protocolos. Analisou-se o tipo de material, ano, país, população, método, Nível de Evidência, e cuidados de enfermagem. A amostra final foi de 33 publicações. Resultados: Dentre os cuidados de enfermagem ao paciente, identificou-se a higienização das mãos, cuidados gerais nos procedimentos de enfermagem, utilização de protocolos, comunicação efetiva e treinamentos periódicos. Conclusão: Identificar os cuidados ao paciente com infecção foi importante para elencar métodos e reorientar as atividades da Enfermagem.

Descritores: Unidades de Terapia Intensiva; Enfermagem; Infecções Relacionadas à Assistência â Saúde; Cuidados de Enfermagem; Pacientes.

\section{RESUMEN}

Objetivo: Identificar y asignar los cuidados de enfermería al paciente adulto con Infecciones Relacionadas a la Asistencia a la Salud internado en Unidad de Terapia Intensiva. Método: Scoping Review, realizado en enero de 2018, mediante la búsqueda de estudios en bases de datos, revistas, catálogos de tesis y disertaciones nacionales e internacionales, además de sitios de instituciones brasileñas de salud. Esto incluye la investigación publicada en su totalidad en portugués, español o Inglés; que tenían como objeto de estudio la temática investigada, además de manuales y protocolos. Se analizó el tipo de material, año, país, población, método, Nivel de evidencia, y cuidados de enfermería. La muestra final fue de 33 publicaciones. Resultados: Entre los cuidados de enfermería al paciente, se identificó la higienización de las manos, cuidados generales en los procedimientos de enfermería, utilización de protocolos, comunicación efectiva y entrenamientos periódicos. Conclusión: Identificar los cuidados al paciente con infección fue importante para elencar métodos y reorientar las actividades de la Enfermería.

Descriptores: Unidades de Terapia Intensiva; Enfermería; Infecciones Relacionadas con la Asistencia Sanitaria; Cuidados de Enfermería; Pacientes. 


\section{INTRODUÇÃO}

The Intensive Care Unit (ICU) is intended for the care of severe patients, who are hemodynamically unstable, requiring constant monitoring and a greater number of invasive procedures ${ }^{(1)}$.

In this way, it is characterized as a critical area of high technological complexity and with a high risk for the development of Healthcare-Associated Infections (HAls), representing an average of $20 \%$ of all infections diagnosed in hospitalized patients ${ }^{(2)}$.

In ICU, HAls are mainly associated with central venous catheters, urinary catheters, mechanical ventilation, prolonged hospitalization and the use of broad spectrum antimicrobials ${ }^{(1)}$.

In this sense, HAls endanger Patient Safety (PS) and constitute the most frequent Adverse Event (AE) in hospital institutions. With higher incidence, we highlight the Urinary Tract Infections (UTI), mechanical Ventilator-Associated Pneumonia (VAP) and Bloodstream Infections (BSI) ${ }^{(3)}$.

Given the severity of infections, cost implications, patient morbidity and mortality, HAls are a worldwide concern. The initiatives to minimize them are increasing and, thus, to promote the promotion of PS and quality of care ${ }^{(4)}$.

Thus, knowing the recommendations for control and prevention of HAls requires joint efforts of all the professionals involved in health care, with strategies that contemplate their various aspects ${ }^{(5)}$.

In the multiprofessional team, Nursing gains visibility, not only because it is the category with the largest number of workers, but because it remains at the patient's side for 24 hours, being present in all health services at different levels of care, besides performing bureaucratic functions, to control hospital infection and to act in teaching and research ${ }^{(6)}$.

A study carried out in 2015 observed that the development of HAls, together with the present complexity of ICU inpatient care, can directly impact nursing care, in order to generate overload for the team. On the other hand, this work overload in ICUs may favor or predispose to the development of $\mathrm{HAls}^{(7)}$.

Thus, it is essential to reduce the care risks in the nursing care process, since it has a direct impact on the PS and the quality of care. In addition, the reduction of risks and damages, besides the incorporation of good practices, favors the effectiveness of the care and its management in a safe way ${ }^{(8)}$.

Therefore, knowing what care is needed for the patient with infection is fundamental to design strategies and reordering the performance of Nursing work in order to minimize HAls and their effects. Therefore, the present study has as a guiding question: What nursing care is performed on the adult patient with HAls admitted to ICU?

\section{OBJECTIVE}

This study aims to identify and map nursing care to the adult patient with HAls admitted to ICU.

\section{METHOD}

Scoping Review, elaborated according to the method recommended by the Joanna Briggs Institute, Reviewers Manual(9), according to the theoretical framework proposed by Arksey and O'Malley(10).
This type of research consists of an exploratory review, designed to map, in scientific production, relevant studies in a given area. Five steps were described: I. identification of the research question; II. Identification of relevant studies; III. Selection of studies; IV. Data analysis; V. Synthesis and presentation of data ${ }^{(9)}$.

In stage I, we established the research question, the purpose of the study and the descriptors were established according to the mnemonic combination PCC (P: Population - C: Concept Nursing Care: C: Context - ICU). The following guiding question arose: What nursing care is performed on the adult patient with HAls admitted to ICU?

The second step consisted of two subdivisions: The first corresponded to the selection of descriptors in studies published and available in the National Library of Medicine (PubMed) and Cumulative Index to Nursing and Allied Health Literature (Cl$\mathrm{NAHL}$ ) databases, as indicated by the manual(9). The descriptors indexed in the controlled vocabulary of Medical Subject Heading Terms (MeSH) were: Patients, Cross Infection, Nursing Care and Intensive Care Units.

In the first search, we used the cross-over: Patients AND Cross Infection AND Nursing Care AND Intensive Care Units to select the largest number of studies in PubMed and CINAHL, in order to identify the most used keywords in the published researches.

After selecting the descriptors and equivalences, the electronic capture of the studies in PubMed, CINAHL, Web of Science, SCOPUS and LILACS databases was performed. These were searched in the CAPES Journals Portal, from the identification through the Federated Academic Community (CAFe - Comunidade Acadêmica Federada), with the selection of the higher education institution Universidade Federal do Rio Grande do Norte (UFRN), as a way of standardizing the collection in these bases in January 2018.

We also searched for publication journals on the subject, so they were included in the search process: American Journal of Infection Control, Infection Control Hospital Epidemiology, and Journal of Hospital Infection.

We also used the gray literature. For dissertations and theses, we searched: Brazil - Theses and Dissertations Catalog of the Coordenação de Aperfeiçoamento de Pessoal de Nível Superior (CAPES - Coordination of Improvement of Higher Education Personnel); European Continent - Europe E-theses Portal (DART); United Kingdom - Eletronic Theses Online Service (EThOS); Portugal - Repositório Científico de Acesso Aberto de Portugal (RCAAP - Scientific Repository of Open Access of Portugal); South African National Theses and Dissertations (ETD Portal); Canada - Theses Canada.

For the selection of manuals and protocols, the websites of the following institutions were searched: Agência Nacional de Vigilância Sanitária (ANVISA - National Sanitary Surveillance Agency), PROQUALIS, Rede Brasileira de Enfermagem e Segurança do Paciente (REBRAENSP - Brazilian Network of Nursing and Patient Safety) and Conselho Federal de Enfermagem (COFEN - Federal Nursing Council).

In the search for the articles to compose the sample, we used the Boolean operators AND and OR, as described in the search strategy: [patients AND cross infection OR nosocomial infection] AND [nursing care OR nursing care OR nursing protocols OR evidence-based nursing OR nursing interventions OR practice guideline] AND [intensive care units OR critical care]. 
It should be emphasized that each data base has its search peculiarities, so it was necessary to adapt the strategy used, however we maintained the similarities in the descriptor combinations for all.

The refinement of the found articles was based on the eligibility criteria. Those of pre-established inclusion were: Research published in full in the Portuguese, Spanish or English language; who had as object of investigation the nursing care to the adult patient with HAls. Also, manuals and protocols published by Brazilian regulatory agencies were included.

Time limit has not been set. Duplicate studies, editorials, reports of experience, theoretical dissertations, reflection studies, books and other reviews, as well as researches that did not present abstract and online text in full, were excluded.

In the third step, the articles were pre-selected from the reading of the titles and abstracts and the final sample was reached based on the reading of the articles in full, according to the flowchart in Figure 1.

The articles were analyzed (fourth stage) by using data collection indicators designated by:Type of material, year of publication, country of origin, population, study method, Level of Evidence, nursing care listed.

The fifth step consisted in the critical analysis of the data. The results were entered in spreadsheets available in the Microsoft Excel $2010^{\circledR}$ program and analyzed by descriptive statistics.

It should be noted that the study was carried out with data from the public domain, thus, ethical appreciation was not necessary.

\section{RESULTS}

From the search in the data sources and according to the inclusion and exclusion criteria, we obtained a total of $33(100 \%)$ publications. Among these, there are articles $(25 ; 75.8 \%)$, manuals (5; $15.1 \%)$, dissertations $(2 ; 6.0 \%)$ and protocols $(1 ; 3.1 \%)$.

Among the articles and dissertations listed, Table 1 highlights the approaches, the methodological designs used and the Levels of Evidence identified.

Nursing professionals (16; 35.0\%), nursing technicians (9; $19.7 \%)$ and patients $(9 ; 19.7 \%)$ predominated in the articles and dissertations.

In relation to the year of publication, there is a highlight for 2017 (10; 30.3\%), followed by 2010 (5; 15.4\%), as shown in Figure 2 . Regarding the country of origin, Brazil stood out $(13 ; 39.5 \%)$ and soon after the United States of America (10; 30.3\%).
Table 1 - Methodological characterization of articles and dissertations, Natal, Rio Grande do Norte state, Brazil, 2018

\begin{tabular}{lll}
\hline \multicolumn{1}{c}{ Characterization } & $\mathbf{n}$ & $\%$ \\
\hline Methodological approah & 27 & 100 \\
Qualitative & 19 & 70.3 \\
Mixed & 05 & 18.5 \\
Quantitative & 03 & 11.2 \\
Methodological design & 27 & 100 \\
Cross-sectional & 10 & 37.1 \\
Descriptive & 09 & 33.3 \\
Experimental & 02 & 07.4 \\
Control & 02 & 07.4 \\
Cohort & 02 & 07.4 \\
Observational & 01 & 03.7 \\
Explanatory & 01 & 03.7 \\
Level of Evidence & 27 & 100 \\
I & 01 & 03.0 \\
II & 02 & 06.1 \\
III & 16 & 48.5 \\
IV & 08 & 24.2 \\
V & 06 & 18.2 \\
\hline
\end{tabular}


In all of the publications, the most evident care was related to the prevention of HAls $(30 ; 90.9 \%)$ and to their control $(3 ; 9.1 \%)$. Chart 1 presents the synthesis of nursing care in the care of patients with HAls, observed in the materials analyzed, in addition to the Level of Evidence of each study that pointed out the care.

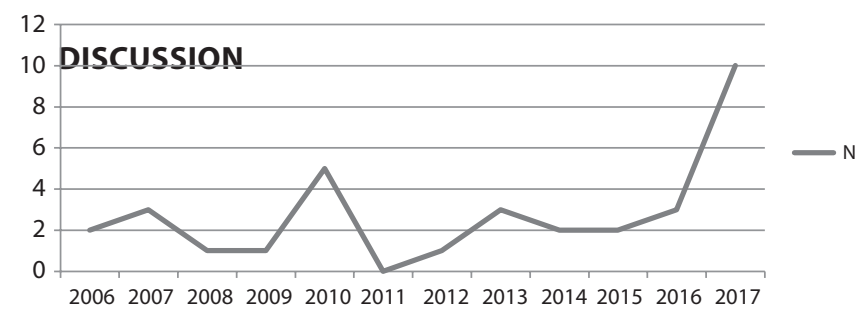

Figure $\mathbf{2}$ - Year of publication of the materials listed in absolute numbers, Natal, Rio Grande do Norte state, Brazil, 2018 (N=27)
There was a highlight in the productions on the subject in the year 2017, this is due - among other factors - the publication of the results of the first version of the Programa Nacional de Prevenção e Controle de Infecções Relacionadas à Assistência à Saúde (PNPCIRAS - National Program for Prevention and Control of Healthcare-Associated Infections), which covered the triennium 2013-2015 $5^{(10)}$, since most of the materials were produced in Brazil.

Thus, several themes have been discussed in this Program, such as the global and national situation of HAls and new goals and objectives of PNPCIRAS (five years 2016-2020)(11).

In Brazil, since 1997, a hospital infection control program has been mandatory in all hospitals ${ }^{(12)}$. However, it was not until 2001 that the diagnosis of $\mathrm{HAl}$ control in Brazil began ${ }^{(13)}$.

Thus, we observed in the literature that the presentation of nursing care strategies related to the prevention and control of

Chart 1 - Nursing care for patients with Healthcare-Associated Infections, Natal, Rio Grande do Norte state, Brazil, 2018

\begin{tabular}{|c|c|c|}
\hline \multicolumn{2}{|r|}{ Description of nursing care } & Level of Evidence \\
\hline \multicolumn{2}{|l|}{ Hands Hygiene } & 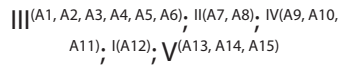 \\
\hline \multirow{3}{*}{ VAP Care } & Oral hygiene & III(A5, A16); IV(A10, A19); $\mathrm{V}^{(\mathrm{A} 15)}$ \\
\hline & Bed head raised at an angle of $30^{\circ}$ to $45^{\circ}$ from the horizontal & $\mathrm{III}^{(\mathrm{A} 5, \mathrm{~A} 16)} ; \mathrm{IV}^{(\mathrm{A} 10)} ; \mathrm{V}^{(\mathrm{A} 15)}$ \\
\hline & Care in monitoring endotracheal cuff pressure & $\mathrm{IV}^{(\mathrm{A} 10)} ; \mathrm{V}^{(\mathrm{A} 15)}$ \\
\hline \multirow{3}{*}{ CVC Care } & CVC maintenance & III(A20, A21, A12); IV (A23); $\mathrm{V}^{(\mathrm{A} 15, \mathrm{~A} 24)}$ \\
\hline & Dressing care & $\mathrm{III}^{(\mathrm{A} 6)} ; \mathrm{IV}^{(\mathrm{A} 23)} ; \mathrm{V}^{(\mathrm{A} 15)}$ \\
\hline & Medication preparation and administration care & III(A4, A6); IV ${ }^{(\mathrm{A} 23)} ; \mathrm{V}^{(\mathrm{A} 24, \mathrm{~A} 15)}$ \\
\hline \multirow{6}{*}{ DVP Care } & $\begin{array}{l}\text { Inserting the catheters only with appropriate indications and keeping them only the neces- } \\
\text { sary time }\end{array}$ & $\mathrm{III}^{(\mathrm{A} 25, \mathrm{~A} 26)} ; \mathrm{V}^{(\mathrm{A} 15)}$ \\
\hline & Use aseptic technique on insertion & $\mathrm{III}^{(\mathrm{A} 25, \mathrm{~A} 26)} ; \mathrm{V}^{(\mathrm{A} 15)}$ \\
\hline & Proper catheter attachment & $\mathrm{III}^{(\mathrm{A} 25, \mathrm{~A} 26)} ; \mathrm{V}^{(\mathrm{A} 15)}$ \\
\hline & Maintenance of the urine collector below the bladder level & III (A26); $\mathrm{V}^{(\mathrm{A} 15)}$ \\
\hline & Maintenance of urine collector drainage every 8 hours or up to $50 \%$ of urine collector & IIII ${ }^{(\mathrm{A} 26)} ; \mathrm{V}^{(\mathrm{A} 15)}$ \\
\hline & Perform routine hygiene of the meatus and whenever necessary & $V^{(A 15)}$ \\
\hline \multirow{5}{*}{ SSI Care } & Care of wound dressings & III (A27) $^{(2)}$ \\
\hline & Maximum precautions for sterile barriers & III (A27) \\
\hline & Chlorhexidine skin antisepsis & III (A27) \\
\hline & Performing a trichotomy before the surgical procedure & III (A27) \\
\hline & Using the Surgical Safety Checklist & $\mathrm{V}^{(\mathrm{A} 14, \mathrm{~A} 15)}$ \\
\hline \multicolumn{2}{|c|}{ Care in the dietary probe administration } & $\mathrm{IV}^{(\mathrm{A} 10)}$ \\
\hline \multicolumn{2}{|c|}{$\begin{array}{l}\text { Use of chlorhexidine-impregnated towels to reduce cross-transmission and colonization by multi-resistant organ- } \\
\text { isms }\end{array}$} & III (A28, A29) \\
\hline \multicolumn{2}{|c|}{ Application of the "contact isolation" protocol } & $\mathrm{III}^{(\mathrm{A} 6, \mathrm{~A} 30)} ; \mathrm{IV}^{(\mathrm{A} 10)}$ \\
\hline \multicolumn{2}{|c|}{ Communication between nurses and doctors } & 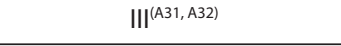 \\
\hline \multicolumn{2}{|c|}{ Use of current and best nursing practices, promote and sustain a climate of safety and high quality care } & $\mathrm{I}^{(\mathrm{A} 12)} ; \mathrm{V}^{(\mathrm{A} 32)} ; \mathrm{IV}(\mathrm{A22})$ \\
\hline \multicolumn{2}{|l|}{ Protocols use } & $\begin{aligned} \mathrm{III}^{(\mathrm{A} 16, \mathrm{~A} 6)} ; & \text { IV } \mathrm{V}^{(\mathrm{A} 17, \mathrm{~A} 11, \mathrm{~A} 19, \mathrm{~A} 22)} ; \mathrm{I}^{(\mathrm{A} 12)} ; \\
& \mathrm{V}^{(\mathrm{A} 13, \mathrm{~A} 18, \mathrm{~A} 15)}\end{aligned}$ \\
\hline \multicolumn{2}{|c|}{ Infection control training } & $\mathrm{I}^{(\mathrm{A} 12)} ; \mathrm{V}^{(\mathrm{A} 14, \mathrm{~A} 15)} ; \mathrm{IV}^{(\mathrm{A} 17)}$ \\
\hline
\end{tabular}

Note - *Mechanically Ventilated Pneumonia (VAP), Central Venous Catheter (CVC), Delay Vesical Probe (DVP), Surgical Site Infection (SSI); ** Codes and references of the articles are presented in appendix. 
HAls involve several segments, from quality management and resources to guarantee work structure, such as hygiene care, health professionals and staff ${ }^{(14)}$.

Therefore, measures for the prevention of HAls should be adopted in health care establishments and by all professionals, since with knowledge and adherence of programs for the prevention and control of HAls it is possible to reduce them by up to $70 \%{ }^{(15)}$.

According to the European Center for Disease Prevention and Control (ECDC), approximately $20 \%$ to $30 \%$ of HAls are considered preventable through intensive hygiene and control programs ${ }^{(16)}$.

From the results, the importance of the nursing professionals' role in the prevention and control of HAls is elucidated, as corroborated by a study ${ }^{(17)}$ that approached nursing practice in the prevention and control of Primary Bloodstream Infection (PBSI) related to the CVC.

Hand Hygiene $(\mathrm{HH})$ is the main care in the prevention of HAls and studies have found that this universal precaution is the cheapest and most effective. However, it is not simple, as it is inherent to the commitment of all involved ${ }^{(14,18)}$.

To this end, the health services must have alcoholic preparation for antiseptic hand rubs at the service and treatment points, with a visible and easily accessible place, in order to avoid having to leave the place of assistance and treatment to hygienize the hands ${ }^{(19)}$.

Regarding the care for VAP identified, the PNPCIRAS (20162020) designates that VAP prevention protocols include, minimally, guidelines to keep patients with headaches elevated between 30 and $45^{\circ}$, to evaluate daily the sedation and to diminish whenever possible, and the performance of oral hygiene with antiseptics ${ }^{(11)}$. In the ANVISA prevention manual, we add the item to routinely subglottic secretion ${ }^{(3)}$.

One study ${ }^{(20)}$ presented the use of bundles instead of isolated prevention measures. With respect to the VAP, in addition to those defined by the PNPCIRAS, it was recommended that mechanical ventilator circuits be performed (periodic replacement of the ventilator circuit, avoid condensation of water in the circuit and daily evaluation of the possibility of extubation), aspiration of the secretion only when necessary, cuff pressure checking (measured every four hours and kept inflated with an ideal pressure of 20 to $30 \mathrm{cmH} 2 \mathrm{O}$ ) and $\mathrm{HH}^{(20)}$.

Already in a study carried out in a ICU in Recife, the VAP bundle, apart from the items mentioned above, was composed of prophylaxis of Deep Vein Thrombosis (DVT)and prophylaxis of peptic ulcer ${ }^{(21)}$, measured without evidence to prevent VAP ${ }^{(3)}$.

The ANVISA protocol suggests as intervention the head elevation of 30-45, its inclusion in the nursing control sheet and promotion of encouragement to clinical notification, if the bed is not apparently in the proper position ${ }^{(3)}$.

Regarding the practice of safe insertion of CVC, according to PNPCIRAS (2016-2020), HH should be performed using the maximum barrier precautions for catheter insertion (use of a cap, mask, sterile apron and gloves, and large sterile fields covering every area to be punctured), prepare the skin with $0.5 \%$ chlorhexidine alcoholic solution or PVPI, select the CVC insertion site, using the subclavian vein as the preferred site for non-tunneled CVC(11).

It was seen that the recommendations for insertion of CVC are summarized in actions taken and observed by the team before, during and after insertion of the catheter, to ensure its maintenance, from the insertion to the daily catheter revision and permanent education of the multidisciplinary team ${ }^{(22)}$.

It should be emphasized that nursing care also needs to encompass the preparation and administration of medications by CVC, so it is essential to proceed with the disinfection of infusion routes before their use $\mathrm{e}^{(22)}$.

Therefore, alcoholic clorexidine or alcohol 70\% should be applied, local inspection and dressing changes should be preferred to transparent dressings, replacing the equipment at intervals of no more than 96 hours (except blood products or lipid products - requiring of a smaller interval) and, finally, to carry out the regular surveillance for $\mathrm{BSI}$ associated with the central lines ${ }^{(22)}$.

Furthermore, there is indication of insertion of the catheter guided by ultrasonography, since complications associated with its placement include vessel lesions, resulting in hematomas, pneumothorax and hemothorax ${ }^{(22)}$. Thus, even if Nursing does not perform such procedure, you must be aware of the main adverse situations that may result from the technique.

There is also a need for care with peripheral insertion catheters, the ANVISA manual ${ }^{(3)}$ recommends $\mathrm{HH}$ and defines that the use of gloves does not replace the need for hand hygiene.

Lower limb veins are not recommended for puncture, unless absolutely necessary, because of the risk of embolisms and thrombophlebitis. We recommend to avoid flexion region, limbs affected by injuries such as open sores, infections in the extremities, veins already compromised, areas with previous infiltration and/or extravasation, areas with other planned procedures ${ }^{(3)}$.

We suggest to carry out friction of the skin with alcohol-based solution, they are chlorhexidine gluconate, with concentration higher than $0.5 \%, 10 \%$ alcoholic povidone-iodine (PVPI) or $70 \%{ }^{(3)}$.

We emphasize that the application time of chlorhexidine is 30 seconds, while that of PVPI is 1.5 to 2.0 minutes. We indicate that the application of chlorhexidine is performed by means of back and forth movements and PVPI with circular movements (from the inside out), and wait for the spontaneous drying of the antiseptic before proceeding to puncture ${ }^{(3)}$.

We recommend to limit the maximum of two attempts of peripheral puncture by professional and, maximum, four, in total. Regarding stabilization and coverage, it has to be understood that any coverage for a peripheral catheter needs to be sterile, and may be semi-occlusive (gauze and sterile adhesive tape) or semipermeable transparent membrane ${ }^{(3)}$.

Regarding bladder catheterization, although it is considered a frequent invasive procedure, it is associated with complications that require the team's efforts to control it. Therefore, it is essential to provide safe, quality and cost-effective, evidence-based nursing care ${ }^{(23)}$.

In addition, it is recommended that the sterile lubricating gel be used only with or without anesthetic (give preference to the use of an anesthetic in a patient with urethral sensitivity) and it is recommended to use a smaller caliber catheter to avoid urethral trauma ${ }^{(3)}$.

Regarding this procedure, the PNPCIRAS (2016-2020) defines that the protocol for prevention of UTI associated with DVP minimally includes guidelines for $\mathrm{HH}$ before and after insertion of the catheter and any manipulation of the system or site, definition of criteria for indications of urinary catheter use and guidelines for insertion, care and maintenance of the urinary catheter ${ }^{(11)}$. 
Regarding the basic practices for prevention, the ANVISA manual identifies the infrastructure for prevention, process surveillance, continuing education and training, correct handling of the catheter ${ }^{(3)}$.

This requires the routine hygiene of the meatus and, where necessary, keeping the collection bag below the level of the bladder, emptying the collection bag regularly using the individual collection container and avoid contact of the drainage tube with the collection container, the entire system when disconnection occurs, breakdown of aseptic technique or leakage ${ }^{(3)}$.

With regard to SSI, it is estimated that SSI can be avoided in up to $60 \%$ of cases, by applying the recommended guidance and prevention measures ${ }^{(1)}$.

The ANVISA manual guides the use of antibiotic prophylaxis, trichotomy - perform only when necessary and do not use blades, blood glucose control in the preoperative and immediate postoperative period, maintenance of normothermia throughout the perioperative period, optimization of tissue oxygenation in peri and post-operation to use preparations containing alcohol in the preparation of the skin, use the WHO Surgical Safety Checklist (SFCL) to reduce the occurrence of harm to the patient, use plastic wound protectors for gastrointestinal and biliary tract surgeries, perform surveillance by actively seeking SSI and educating patients and family members about SSI prevention measures ${ }^{(3)}$.

With regard to bath and SSI, the patient needs to be advised to take a bath with soap and water before performing the surgical procedure (the night before or on the morning of surgery), except for some special cases in which the bath with antiseptics, as in large surgeries and implant surgeries ${ }^{(3)}$.

We emphasize the importance of oral hygiene. In cases where there is prediction of orotracheal intubation, perform oral hygiene with chlorhexidine $0.12 \%$. Provide clean towels to the patient for the pre-operative bath and proceed to change the patient's clothes and bed or the transport bed after the bath ${ }^{(3)}$.

Also, according to the diagnostic criteria for HAls published by ANVISA ${ }^{(1)}$, the process indicators for the prevention of pre and intraoperative SSI are elective surgeries with preoperative time of less than 24 hours, trichotomy with shorter interval than two hours, trichotomy with trimmer or scissors, antibiotic prophylaxis performed up to one hour before the incision and duration of antibiotic prophylaxis, antisepsis of the operative field.

The basic purpose of a precaution system is to prevent the transmission of a microorganism from one patient to another, or to a health care provider. This prevention covers measures related to the transmission of the agents involved and contemplates three types: Standard, specific and empirical precaution ${ }^{(24)}$.

Regarding the use of protocols exposed in the results, it is evidenced that these are implanted in the institution from own documents about the evaluated item and the accomplishment of training directed to the health professionals with presentation of programming and presence list ${ }^{(11)}$.

The protocol must have a maximum of three years of date of publication or revision and may be included in the content of general protocols of the health service. Thus, the use of protocol improves the safety and quality of care in the ICU, but requires the adherence and periodic training of the multidisciplinary team so that they can be considered quality indicators ${ }^{(11)}$.

Regarding training, it is corroborated by another research (23), which presents as the main recommendation for HAls-related care, the permanent education of the multiprofessional team.

We emphasize that the nurse, as a member of the health team, is responsible for the prevention and systematic control of nosocomial infection and of communicable diseases in general(25).

Therefore, the nurse can contribute, minimizing the fragility between education and the implementation of measures, through adherence and supervision, thus achieving a reduction in infection rates ${ }^{(22)}$.

\section{Study limitations}

As a limitation of the research, it is important not to include legislation from other countries, only from Brazil. In addition, it is noted that some articles were excluded from the sample because they were not freely available in full.

\section{Contributions for the sectors of Nursing, Health or Public Policy}

Identifying the care inherent to the patient with infection is important to list methods and reorient the performance of Nursing work, in order to minimize HAls and their consequences, since they have a direct impact on PS and quality of care, as well as cost repercussions, the morbidity and mortality of patients.

\section{CONCLUSION}

Nursing care for adult patients with HAls hospitalized in ICU identified in this review were hand hygiene, care for the patient using mechanical ventilation, CVC, DVP, and those submitted to surgical procedures.

Also, attention was paid to the routine of care practice, such as the administration of diet by catheter, care related to the patient's ICU bath, interprofessional communication, best nursing practices, promoting safety and high quality care, the use of protocols and the conduction of training on infection control.

Therefore, we recommend that other studies of the same design be carried out in order to address other phases of the nursing process, such as nursing diagnoses, private nurse assignment.

\section{REFERENCES}

1. Agência Nacional de Vigilância Sanitária-ANVISA. Critérios diagnósticos de Infecções Relacionadas à Assistência à Saúde [Internet]. Brasília: ANVISA; 2017[cited 2018 Jan 20] Available from: http://portal.anvisa.gov.br/documents/33852/3507912/Caderno+2+-+Crit\%C3\%A9ri os+Diagn\%C3\%B3sticos+de+Infec\%C3\%A7\%C3\%A3o+Relacionada+\%C3\%A0+Assist\%C3\%AAncia+\%C3\%A0+Sa\%C3\%BAde/7485b4 5a-074f-4b34-8868-61f1e5724501 
Nursing Care in Healthcare-Associated Infections: A Scoping Review Ferreira LL, Azevedo LMN, Salvador PTCO, Morais SHM, Paiva RM, Santos VEP.

2. Osman MF, Askari R. Infection control in the intensive care unit. Surg Clin North Am [Internet]. 2014[cited 2018 Jan 20];94(6):1175-94. Available from: https://www.ncbi.nlm.nih.gov/pubmed/25440118

3. Agência Nacional de Vigilância Sanitária-ANVISA. Medidas de Prevenção de Infecção Relacionada à Assistência à Saúde. Brasília: ANVISA; 2017[cited 2018 Jan 20]. Available from: http://portal.anvisa.gov.br/documents/33852/3507912/Caderno+4+-+Medidas+d e+Preven\%C3\%A7\%C3\%A3o+de+Infec\%C3\%A7\%C3\%A3o+Relacionada+\%C3\%A0+Assist\%C3\%AAncia+\%C3\%A0+Sa\%C3\%BAde/ a3f23dfb-2c54-4e64-881c-fccf9220c373

4. Oliveira AC, Paula AO. Infecções relacionadas ao cuidar em saúde no contexto da segurança do paciente: passado, presente e futuro. Rev Mineira Enferm[Internet]. 2013[cited 2018 Jan 20];17(1):216-20. Available from: http://reme.org.br/artigo/detalhes/592

5. Oliveira AC, Paula AO, Iquiapaza RA, Lacerda ACS. Infecções relacionadas à assistência em saúde e gravidade clínica em uma unidade de terapia intensiva. Rev Gaúcha Enferm [Internet]. 2012[cited 2018 Jan 20];33(3):89-96. Available from: http://www.scielo.br/pdf/rgenf/ v33n3/12.pdf

6. Novaretti MCZ, Santos EV, Quitério LM, Gallotti RMD. Sobrecarga de trabalho da Enfermagem e incidentes e eventos adversos em pacientes internados em UTI. Rev Bras Enferm [Internet]. 2014[cited 2018 Jan 20];67(5):692-9. Available from: http://www.scielo.br/pdf/reben/ v67n5/0034-7167-reben-67-05-0692.pdf

7. Nogueira LS, Ferretti-Rebustini REL, Poveda VB, Gengo e Silva RC, Barbosa RS, Oliveira EM, et al. Carga de trabalho de enfermagem: preditor de infecção relacionada à assistência à saúde na terapia intensiva? Rev Esc Enferm USP [Internet]. 2015[cited 2018 Jan 20];49(Esp):36-42. Available from: http://www.scielo.br/pdf/reeusp/v49nspe/1980-220X-reeusp-49-spe-0036.pdf

8. Joanna Briggs Institute. Reviewer's manual: 2015 edition/supplement. The University of Adelaide, Austrália: JBI; 2015.

9. Arksey H, O’Malley L. Scoping studies: towards a methodological framework. Int J Soc Res Methodol. 2005;8(1):19-32.

10. Agência Nacional de Vigilância Sanitária-ANVISA. Programa Nacional De Prevenção e Controle De Infecções Relacionadas à Assistência à Saúde (2013 - 2015) [Internet]. Brasília: ANVISA; 2013[cited 2018 Jan 20]. Available from: http://portal.anvisa.gov.br/ documents/33852/272166/Programa+Nacional+de+Preven\%C3\%A7\%C3\%A3o+e+Controle+de+Infec\%C3\%A7\%C3\%B5es+Relacionadas+ \%C3\%A0+Assist\%C3\%AAncia+\%C3\%A0+Sa\%C3\%BAde+\%282013-2015\%29/d1d0601f-004c-40e7-aaa5-0af7b32ac22a

11. Agência Nacional de Vigilância Sanitária-ANVISA. Programa Nacional de Prevenção e Controle de Infecções Relacionadas à Assistência à Saúde (2016-2020) [Internet]. Brasília: ANVISA; 2016[cited 2018 Jan 20]. Available from: http://portal.anvisa.gov.br/ documents/33852/3074175/PNPCIRAS+2016-2020/f3eb5d51-616c-49fa-8003-0dcb8604e7d9?version=1.1

12. Ministério da Saude (BR). Lei $\mathrm{N}^{\circ}$. 9.431, de 06 de Janeiro de 1997. Dispõe sobre a obrigatoriedade de manutenção de programas de controle de infecção hospitalar pelos hospitais do país [Internet]. Brasília, 1997[cited 2018 Jan 20]. Available from: http://www.planalto.gov.br/ ccivil_03/leis/l9431.htm

13. Agência Nacional de Vigilância Sanitária-ANVISA. Diagnóstico do controle de infecção hospitalar no Brasil. Brasília, 2005[cited 2018 Jan 20]. Available from: http://www.anvisa.gov.br/servicosaude/controle/Infectes\%20Hospitalares_diagnostico.pdf

14. Oliveira HM, Silva CPR, Lacerda RA. Policies for control and prevention of infections related to healthcare assistance in Brazil: a conceptual analysis. Rev Esc Enferm USP [Internet]. 2016[cited 2018 Jan 20];50(3):502-8. Available from: http://www.scielo.br/pdf/reeusp/v50n3/ pt_0080-6234-reeusp-50-03-0505.pdf

15. Centers for Disease Control and prevention-CDC. Healthcare-Associated Infections-HAI. Progress Report [Internet]. 2016[cited 2018 Jan 20]. Available from: https://www.cdc.gov/hai/surveillance/progress-report/

16. European Centre for Disease prevention and Control-ECDC. Health care-associated infections. 2016[cited 2018 Jan 20]. Available from: http://ecdc.europa.eu/en/healthtopics/healthcare-associated_infections

17. Mendonça KM, Neves HCC, Barbosa DFS, Souza ACS, Tipple AFV, Prado MA. Atuação da enfermagem na prevenção e controle de infecção de corrente sanguínea relacionada a cateter. Rev Enferm UERJ [Internet]. 2011[cited 2018 Jan 20];19(2):330-3. Available from: http://www. facenf.uerj.br/v19n2/v19n2a26.pdf

18. Pina E, Ferreira E, Uva MS. Infecções associadas aos cuidados de saúde. In: Souza P, Mendes W. Segurança do paciente: conhecendo os riscos nas organizações de saúde. Rio de Janeiro: EAD/ENSP; 2014:137-58.

19. Agência Nacional de Vigilância Sanitária-ANVISA. RDC n 42, de 25 de outubro de 2010. Dispõe sobre a obrigatoriedade de disponibilização de preparação alcoólica para fricção antisséptica das mãos, pelos serviços de saúde do País, e dá outras providências [Internet]. Brasília: ANVISA; 2010[cited 2018 Jan 20]. Available from: https://www20.anvisa.gov.br/segurancadopaciente/index.php/legislacao/item/ rdc-42-de-25-de-outubro-de-2010

20. Chicayban LM, Terra ELVS, Ribela JS, Barbosa PF. Bundles de prevenção de pneumonia associada à ventilação mecânica: a importância da multidisciplinaridade. Perspect O: Biol Saúde [Internet]. 2017[cited 2018 Jan 20];7(25):25-35. Available from: http://www.seer. perspectivasonline.com.br/index.php/biologicas_e_saude/article/view/1200

21. Almeida KMV, Barros OMC, Santos GJC, Valença MP, Cavalcanti ATA, Ferreira KO. Adesão às medidas de prevenção para Pneumonia Associada à Ventilação Mecânica. Rev Enferm UFSM [Internet]. 2015[cited 2018 Jan 20];5(2):247-56. Available from: https://periodicos.ufsm. $\mathrm{br} / \mathrm{reufsm} /$ article/view/15411/pdf

22. Henrique DM, Tadeu CN, Alves FH, Trindade LPC, Fernandes MSR, Macedo ML, et al. Fatores de risco e recomendações atuais para prevenção de infecção associada a cateteres venosos centrais: uma revisão de literatura. Rev Epidemiol Control Infect [Internet]. 2013 [cited 2018 Jan 
20];3(4):134-8. Available from: https://online.unisc.br/seer/index.php/epidemiologia/article/viewFile/4040/3252

23. Ercole FE, Macieira TGR, Wenceslau LCC, Martins AR, Campos CC, Chianca TCM. Revisão integrativa: evidências na prática do cateterismo urinário intermitente/demora. Rev Latino-Am. Enfermagem [Internet]. 2013[cited 2018 Jan 20];21(1):[10 telas]. Available from: http://www. scielo.br/pdf/rlae/v21n1/pt_v21n1a23

24. Center for Disease Control-CDC. Update: guideline for isolation precautions: preventing transmission of infectious agents in healthcare settings [Internet]. 2007[cited 2018 Jan 20]. Available from: https://www.cdc.gov/infectioncontrol/guidelines/isolation/index.html

25. Ministério da Saúde (BR). Lei №. 7.498, de 25 de junho de 1986. Dispõe sobre a regulamentação do exercício da enfermagem, e dá outras providências [Internet]. Brasília; 1986[cited 2018 Jan 20]. Available from: http://www.planalto.gov.br/ccivil_03/leis/l7498.htm 